\title{
Intergovernmental Relations in Scotland Post-Devolution
}

\author{
NEIL McGARVEY
}

In the past few years government at every level in Scotland has been subject to significant upheaval. In 1996 the mainland local government structure was reformed from a two-tier structure of 53 district and nine regional councils to 29 unitary authorities, in 1997 the Labour Party took control of the Scottish Office after 18 years of Conservative rule and in 1999 the Scottish Office was 'democratised' with the establishment of a parliament and re-named the Scottish Executive. The rhetoric surrounding devolution was that it represented a new dawn for Scottish politics (see McGarvey, 2001a; Mitchell, 2001 for reviews of post-devolution literature). This article seeks to outline the changes which have taken place and seeks to assess their implications for central-local relations in Scotland. ${ }^{1}$ Before doing so it is necessary to set the scene and outline the pre-devolution picture of Scottish central-local relations.

Pre-devolution as an integral part of British government, the Scottish Office and Scottish local government have experienced the same policy initiatives as the rest of the UK. There has, however, been some distinctiveness in terms of administrative structure and practice, with considerable scope for autonomy in implementation. There was a 'tartanisation' of UK policy initiatives by the Scottish Office. Policies towards local government were different to a degree, but the overall substance and rationale behind them tended to be very similar.

The tone of central-local government relations in Scotland during the Conservative years was similar to that of England and Wales. Numerous UK studies have recorded the deterioration in relations between central and local government since 1979, and the increased reliance on mechanisms of control rather than understandings or conventions (see Dunleavy, 1997; Hood et al., 1999; Rhodes, 1988; 1997; Stoker 1999; 2000a). The House of Lords Hunt Report in 1996 talked of 'incrementally soured relations, weakened local democracy and blurred accountability' (House of Lords, 1996: 5) in central-local relations.

Neil McGarvey, University of Strathclyde 
However, relations never quite deteriorated to the same extent in Scotland as they did south of the border. Scottish Office oversight of local councils has reflected its more consensual style (Midwinter et al., 1991). This is not to say there have not been problems - Compulsory Competitive Tendering (CCT), rate-capping, the poll tax and structural reorganisation, all contributed to increased tensions. However, there has not been the same corrosive lack of trust that was evident in England (see Lowndes, 1998). The small-scale nature of central-local relations in Scotland is reflected in the close physical proximity and the interpersonal relations between members of the Convention of Scottish Local Authorities (COSLA), Scottish civil servants and politicians. The concept of 'village life' in Whitehall identified by Heclo and Wildavsky (1981) retains a strong resonance in Scottish central-local relations with direct contacts possible in smaller policy networks (Midwinter and McGarvey, 2001: 847).

Post-devolution Scottish local councils are pivotal institutions for the Scottish Executive delivering on its commitment to make a difference to their lives of ordinary Scottish people. Local government is a key partner in the Scottish Executive's desire to deliver on the social justice agenda that forms the framework of the programme for government. Councils are critical to the executive delivering its key pledges and objectives such as strong communities, an enterprising workforce and sustainable development. On a broader level, councils are also important for delivering on devolution's objectives of strengthened democratic control and political accountability in Scotland.

\section{THE NEW PARLIAMENT}

Before examining executive-local government relations it is worth noting how the parliament has dealt with local government. The 'village life' nature of politics in Scotland, noted above, did not prevent concerns over the impact of devolution on local government (see Alexander, 1997; Sinclair, 1997; Himsworth, 1998). However, the devolution White Paper (Scottish Office, 1997: para.6.7) made it clear that the government did not envisage the parliament taking powers from local authorities.

There is no doubt, however, that the arrival of the parliament changed the context of local government in Scotland. As the Commission on Local Government noted:

The arrival of the Scottish Parliament represents a fundamental change in the political landscape within which Scottish councils in future will operate. Although Parliament and local government each have a democratic base, the Parliament will have the ultimate power 
of determining what becomes of local government. (McIntosh Commission, 1999: 11)

At the UK level, the reality of central-local relations is that it is primarily about executive-council relations. In Scotland that still appears to be the case, though the Scottish Parliament is emerging as a more important actor than its Westminster counterpart. The backdrop of the parliament has heightened democratic scrutiny. The main concern pre-devolution was that it could be a means of enhancing political control by increasing the scope of ministerial supervision and parliamentary scrutiny of local government beyond what was possible at Westminster. Democratic scrutiny of Scottish local government was previously rare and is now a daily occurrence, with numerous parliamentary committees taking an interest in the activities of councils. The Scottish Parliament Local Government Committee generally takes a supportive position vis-à-vis local government, but still exposes its representatives to critical questioning. For example, the decision to hold an inquiry into local government finance followed representations to it by Neil McIntosh (former Strathclyde Regional Council chief executive) and COSLA.

However, so far the parliament's efforts at influencing local government have been frustrated by lack of adequate financial information. The politics of local government finance have always been complex and moves are under way to make financial information more transparent for the committee.

To date the parliament has not wielded the influence on localities it may wish to. However, in the longer term it will increase the pressure on localities as they seek to respond to the initiatives of the centre. This adds to the possibility of an erosion of the powers of local government as a consequence of devolution. The Scottish Parliament stripped many local councils of their most able leaders, it is thus not surprising that it is difficult to detect a strong sense of leadership within Scotland's councils. The idea of directly elected provosts drifted around the agenda in the late 1990s, but it never mustered enough support within councils to be considered seriously.

\section{COMMISSION ON LOCAL GOVERNMENT AND \\ THE SCOTTISH PARLIAMENT}

The first debate conducted in the parliament was directly related to this question. Prior to devolution the Scottish Office established a commission to look into the relationship between the Scottish Parliament and local government. The recommendations of what has become known as the 
McIntosh Report were wide-ranging, covering relations with the parliament and ministers, electoral arrangements and electoral reform, the conduct of council business and the role of community councils. All these elements have an influence on relationships between local government and the Scottish Parliament and Scottish Executive.

The Scottish Executive accepted the overwhelming majority of the recommendations. Following on from it numerous new bodies were established with an explicit focus on various aspects of central-local relations: a community leadership forum; a renewing local democracy working group (the Kerley Group); a leadership advisory panel (the MacNish Group). The executive and the parliament have responded to each of the six key recommendations in the McIntosh Report.

The first one was 'The Parliament and the 32 councils should commit themselves to a joint agreement - which we call a Covenant - setting out the basis of their working relationship'. The parliament's local government committee invited COSLA to prepare a draft of a covenant for discussion. COSLA's main concern was to give local government parity of esteem in terms of engaging with all aspects of the parliament's work which affects the structure, role and financing of local government. Secondary questions were how local government should engage with constituency and list MSPs and any special interest groups which may be set up within the parliament. The second recommendation was that parliament and local government should set up a standing joint conference to be a place where parliamentarians and local government representatives may hold a dialogue on a basis of equality. This had led to the establishment of a community leadership forum bringing together ministers, leaders of all 32 councils and the convener of the parliament's local government committee to engage in discussion. The first meeting was held in September 1999.

The third recommendation was that a formal working agreement should be established between local government and the Scottish ministers. A working agreement between local government and the Scottish Office was drawn up soon after the general election in 1997. This has been superseded by the partnership framework announced in May 2001 (see below).

The fourth recommendation, that legislation should be introduced to provide councils with a statutory power of general competence, is forming part of the Local Government Bill going through the Scottish Parliament at the moment. The bill will free councils from the limitations of existing rules by allowing them more flexibility to do anything that promotes the wellbeing of their area.

The fifth recommendation has proved the most troublesome. It suggested that an independent inquiry into local government finance should be instituted immediately. The executive rejected this recommendation, arguing 
that there was not a proven link between the percentage of money raised locally and the question of accountability. In any case, the scope for changing the percentage of locally raised income was limited since localising business rates, cutting the levels of rate support grant, or centralising local authority services such as education were all unacceptable to the executive. The fundamental root and branch independent inquiry was thus rejected. The executive and COSLA did, however, agree to look jointly at the pooling of funding streams between central government, local government and other public bodies and to look at new ways of drawing in private sector resources. They have also sought ways of promoting greater long-term stability in financing, and improving financial management in, local government.

The final McIntosh recommendation was that the option of transfer to local government should always be considered in any review of other bodies delivering public services; and likewise where new services are developed, prior consideration should always be given to whether local government should be their vehicle, subject to consideration of efficiency and costeffectiveness. In light of this, ministers confirmed that they have no plans to take any major functions away from local government and under the Scottish Executive's review of public bodies one of the questions bodies are required to ask themselves is: 'Could the function be put under local authority control?' This was, of course, welcomed by COSLA, its stated position being that such bodies should wherever possible be brought under local democratic control.

\section{KERLEY REPORT}

As noted above, the Renewing Local Democracy Working Group was established after the recommendation included in the McIntosh Report. Appointed by Scottish ministers in July 1999, chaired by Richard Kerley (a University of Edinburgh academic), it published its report in June 2000. The Group was asked by ministers to consider many of the recommendations from the McIntosh Report and suggest ways in which council membership could be made more attractive to a wider cross-section of the community, and how councils could become more representative of the make-up of the community they serve. It made 36 recommendations to improve the health of local democracy in Scotland, most relatively uncontroversial. It reviewed the creation of a more proportional electoral system, the remuneration of councillors and the electoral cycle. These are all aimed at promoting accountability in local councils and making it more outward-looking, which will make local government easier to access and easier to understand. The suggestion in much recent literature on local governance (Stoker, 1999; Stoker, 2000) is that accountability is a problem (see McGarvey, 2001b). 
One of the main issues it looked at was council leadership. The Kerley Report has recommended that Scotland's top council leaders should be paid the same as MSPs. This is in line with the agenda in England that has emphasised the need for new styles of leadership in local councils, with elected leaders taking a more prominent and pivotal role (see Leach and Wilson, 2000).

The report also recommended more renumeration for councillors who carry significant additional responsibilities and that at least one of these be a councillor who is not a member of the ruling group. It also suggests that the abolition of the salary threshold for politically restricted posts be abolished (making the nature of each post the sole determinant of political restriction). It advised on the appropriate numbers of members for each council, taking account of proportionality. A minimum of 19 and maximum of 53 members was recommended (with the exception of Highland Council). It emphasised the importance of the ward-councillor link; fair provision for independents; allowance for geographic diversity; and close fit between council wards and natural communities. To broaden access to councils, it also recommended a review of business procedures and administrative support to facilitate councillors carrying out their role on a part-time basis, the encouragement of greater participation of people with disabilities, women and ethnic minorities on councils and lowering the current age limit for standing as a councillor from 21 to 18 .

However, the central and most politically sensitive issue Kerley reported on was that of electoral reform. The issue is very sensitive for the ruling Labour-Liberal Democrat coalition. In considering its remit, the final report comes down in favour of single transferable vote (STV) (with three dissenters). It then suggests the introduction of STV with flexibility in ward sizes - ranging from three- to five-members wards (or even two in sparsely populated areas). This recommendation was not well received by Labour councillors within Scottish local government. The vast majority of Labour councillors (obviously fearful of their council membership) - some 78 per cent - are opposed to proportional representation in local government (Clarke, 2000). In response, the executive has set up a ministerial sub-group to consider how the executive can - or should respond to Kerley's recommendations. The Scottish Local Government (Elections) Bill introduced into the parliament in autumn 2001 incorporates many of Kerley's recommendations, including proposals to increase local council terms from three to four years and allow councils to run pilot schemes to improve voter turnout and election administration. It was silent on electoral reform. 


\section{LEADERSHIP ADVISORY PANEL}

In the case of organisational structure, Scotland has adopted a less directive approach than in England and Wales, where a statutory approach was taken to prescribe a menu of options. The Local Government Act 2000 requires most local authorities in England and Wales to choose one of three 'modernising' options: elected mayor and cabinet/executive; an appointed leader and executive; or an elected mayor and council manager. All local authorities above 85,000 in population were required to adopt an executive model (Jones and Stewart, 2001). In Scotland there was less prescription, although the McIntosh Report did recommend that 'councils should give particular consideration to formalising the political leadership as an executive, but should also be able to consider other options' (McIntosh, 1999: 6).

The Commission on Local Government and the Scottish Parliament recommended that every council carry out a review of its management of business and working practices assisted by the Leadership Advisory Panel (McIntosh, 1999: Chapter 5). The argument is made that the political executive model would provide the basis for greater scrutiny and accountability of council decision-making.

The Leadership Advisory Panel was set up in 1999 to advise councils and outline the progress of Scotland's 32 councils in their self-reviews of political management arrangements, in line with the recommendations of the Commission on Local Government and the Scottish Parliament. Councils were thus encouraged to review their political decision-making processes designed to enhance transparency, scrutiny, inclusiveness and accountability. The picture presented in the final Leadership Advisory Panel Report (2001: 4) is one

of progress being made across the country, and a rich diversity of models that reflects the degree to which councils have thought carefully about developing structures suited to their particular needs. The process has shown that councils are not just receptive to the theory of modernisation but are actively pursuing real improvements.

The panel based their judgement of councils' plans for change against the following criteria:

- Council business should be managed in such a way that policy proposals and matters for decision by the council are subject to open debate.

- The council must be able to effectively scrutinise the actions of the leadership or executive and hold it to account for its performance. 
- The work of the council should take place, as far as possible, in public and free from unnecessary constraints imposed by the use of the party whip.

- Council business should be organised in such a way which allows as wide a cross-section of the community as possible to realistically consider becoming a councillor

The report categorises the new structures in the 32 Scottish local councils as fitting into one of three general categories:

- Streamlined committee structures $(n=23)$;

- Executives $(n=6)$;

- Devolved and partially devolved structures $(n=3)$.

Given the McIntosh recommendation, it is perhaps surprising that so few councils have gone down the 'executive model' route. Those that did received very positive commentary in the report. The less favourable commentary was reserved for councils which adopted a more conservative approach to change (for example, Angus, Dundee, East Ayrshire, Glasgow and Inverclyde). Evolution rather than revolution would be a fair summary of the vast majority of the approaches adopted by the councils. The executive model would appear to have been rejected by the vast majority of Scotland's councils.

This is perhaps not surprising. Midwinter notes how analysis in favour of the executive model was 'heavily influenced by the urban situation, where party group discipline tends to be more developed' (2000: 2). The concern in these areas is with group politics and patronage in Labourdominated central Scotland which raise questions about accountability and transparency. Outside urban areas, in more open council systems, leaders still have to convince councillors of the merits of their proposals. The Widdicombe (1986) report in the late 1980s rejected the executive model, empirical research that informed it highlighting how the bulk of committee decisions were consensual and non-divisive (Midwinter, 2000: 3).

\section{BEST VALUE}

Like England and Wales, Best Value is a policy that has dominated central-local relations in Scotland. The Scottish approach to Best Value reflects the distinctive nature of Scottish central-local relations. For the Scottish Executive, Best Value represents the defining touchstone of the new central-local government relationship in Scotland. A partnership approach was developed by a Best Value task force (BVTF) which included the executive, COSLA and the Accounts Commission. Best Value plans are 
not approved by the executive, but remain mechanisms for internal management and public reporting. There is an absence of direct regulatory power - Best Value is seen in the executive as a means to persuade councils of the merits of particular approaches to management (see Midwinter and McGarvey, 1999). The Scottish Executive has retained a 'light touch' oversight role reminiscent of the Scottish Office consensual style of operation (ibid.).

The Scottish system is less directive than the Department of Local Government, Transport and the Regions (DLTR) (previously DETR Department of Environment, Transport and the Regions) in England and Wales, with Scottish Executive ministers not acquiring the same new specific and directive powers as their counterparts in Whitehall. For example, in England and Wales the Best Value legislation gives central government new powers of 'flexible and constructive intervention' (DETR, 1998: 31) where local authorities are failing to remedy performance failure. No such provision exists in Scotland. There also appears to be less emphasis on competition and open tendering, perhaps reflecting the experience of CCT in Scotland, where the vast majority of contracts were not externalised.

Despite these differences, there are similar problems. For example, that Best Value involves too much by way of pedagogical concern with the examination of precise documentation, with strict adherence to specified planning and procedures to the neglect of its aspiration. Requirements such as the publication of local performance and service plans, the use of performance indicators, bench marking, consultative exercises and competition as a tool, reflect general prescribed 'rules' local councils should build into their Best Value frameworks.

The Best Value framework in Scotland (just as in England and Wales) reflects the centralist characteristics of UK government. As successive narratives of the post-war history of local government have argued, the focus on internal rules, checks and procedures (process) was to the neglect of a sufficient focus on performance. In other words, there may be a danger that in designing Best Value frameworks councils may become overly concerned with process as opposed to achieving better service outcomes the aim of Best Value.

Moreover, the 'in-house' culture of many local authorities in Scotland has not simply disappeared with the talk of modernisation. CCT highlighted that many commercial companies are not particularly keen on working with/for local councils which are unwilling partners. Commercial companies tend to seek long-term partnerships characterised by trust, reciprocity and a collaborative environment of openness and honesty, this being far more likely to encourage innovation and improvement. The extent to which such an environment exists in Scottish councils at present is 
questionable. There remain many Labour councillors still sceptical of the benefits of involving commercial partners in council operations (BVTF, para.48). As the latest BVTF report noted, 'there are still those who instinctively prefer or are more comfortable with direct delivery of services' (para.47).

There is the distinct possibility that Best Value will be absorbed by Scottish councils in a fatalistic manner with negligible effect on service delivery and the legacy of increased bureaucracy in the form of a new set of internal rules, checks, procedures and reporting frameworks. It is not difficult to imagine a scenario where councils are 'ticking all the right boxes' (or, in more modernising government-speak, 'pressing all the right key-pads') with little substantive effect on service delivery outcomes. Much of the recent history of local government management reform is the story of structural and process reform which had negligible impact on actual policy outputs.

Moreover, Best Value has been thrown into disrepute by the way it has been attached to what are ultimately politically driven decisions - both South Lanarkshire and Glasgow were earlier this year reported to be undertaking 'Best Value reviews' of their COSLA membership. If this demonstrates nothing else it is that in the final analysis decision-making in local government is political, not managerial.

\section{COMMUNITY PLANNING}

Community planning as a policy in Scotland began in 1998 with the establishment of five pathfinder councils to pilot the initiative (one of the few examples of Scotland following the English example of piloting). Community planning is an example of 'joined up government' at the local level. Lloyd and Illsey (1999) define it as best

viewed in terms of any process of public administration through which a Council comes together with other organisations to plan, provide for, or promote the well-being of communities they serve. In other words, community planning represents an attempt to provide a strategic framework for the activities of multifarious institutions engaged in community capacity building and regeneration.

The Community Planning Working Group report in 1998 argued that community planning was required because of the lack of strategic structure to existing partnerships and the requirement for a shared strategic vision for an area and a statement of common purpose (para.11). It requires that local councils act as facilitators of institutions involved in local governance in order to co-ordinate policies, activities and resources to achieve shared goals. 
By 2000 the Scottish Executive was talking of providing a statutory basis for community planning and, in particular, to provide councils with a power of community initiative (what had been called a power of general competence in the commission's report). This was welcomed by COSLA, which has long campaigned for recognition of this role and sees the power of community initiative as giving expression to the community leadership role of councils by giving them more freedom to act in the interests of their communities. Accompanied by a statutory duty of community planning, this would confirm the central role of local authorities as the democratically elected representatives of Scotland's communities. COSLA also noted the clear linkage between community planning and Best Value. Community planning involves councils and their partners examining their service delivery arrangements and creates opportunity for the exploitation of joint working and innovative solutions to service delivery.

The policy is closely linked with notions of joined up holistic government and is also clearly linked to the executive's priority of delivering social inclusion. It is also linked with other 'joined up' initiatives such as new community schools, healthy living centres and public-private partnerships. All of these initiatives are designed so that Scottish local councils become more outward in focus and better equipped to deliver more responsive services.

\section{FINANCE}

The Scottish Executive inherited a very centralised system of local government finance. It is characterised by a high degree of grant dependency, based on an inelastic property tax, under a strict capping regime to control expenditure (Midwinter and McGarvey, 1997). The reform emphasis has been to develop a partnership approach which assures local delivery of national priorities and provides stability so that local authorities can plan on a long-term basis.

With regard to budgeting, the comprehensive spending review (CSR) process has seen the executive working with local government representative associations such as COSLA, SOLACE (Society of Local Authority Chief Executives), CIPFA (Chartered Institute of Public Finance and Accounting), ADES (Association of Directors of Education) and ADSW (Association of Directors of Social Work) in developing joint planning and co-determination of priorities. This could be an example of the much-vaunted 'new politics' in action - key political institutions seeking a consensus around expenditure that covers key areas of national and local policy-making (Mair, 2000: 114). However, one could argue that it is much like the old Scottish Office consultation process, with the usual relevant and credible groups on the inside 
track. Of course, such developments are still at a very early stage - the real test of these partnerships will come during climates of expenditure cutback and retrenchment. At present the fiscal outlook is beginning to look less rosy and the durability of such partnerships may be tested.

There is an ongoing internal Scottish Executive review of local government finance. However, this is not of the comprehensive scale recommended by McIntosh, the focus being movement towards three-year budgeting, grant distribution, and agreements on outcomes. Simultaneously, the local government committee of the parliament is undertaking a wideranging inquiry into local government finance. McIntosh recommended the abolition of crude and universal capping and more stability in grant provision to councils. The executive did not fully accept this - capping has been relaxed although it is still kept as a reserve power. However a threeyear timetable has been introduced to give more certainty to the grant allocation process.

Other post-devolution developments are the encouragement being given to public-private partnership arrangements (see Hood and McGarvey, forthcoming), the large-scale voluntary transfers (LSVT) proposed for council housing, and the pooling of funding streams. The Scottish Executive and COSLA are involved in a joint working group to examine ways of securing better outcomes in terms of service delivery from existing budgets, with emphasis on targeting resources to priorities agreed with the executive (rather than simply to specific services). The overall aim involves linking some part of the grant allocation to a forward plan prepared by each authority, identifying areas and indicators of how services would be improved.

Finance will be the real test of central-local relations post-devolution. It is too early to assess the impact of these ongoing changes, but one is struck by the extent to which the Scottish Executive is in control of the agenda. It rejected the McIntosh calls for a review of finance, new monies are increasingly earmarked and ring-fenced to reflect executive policy priorities and capping remains as a reserve power. To the frustration of some in local government, the executive has increasingly used ring-fencing as a lever to ensure delivery of specific policy initiatives at a local level. Representatives of COSLA stated in evidence to the Local Government Committee:

virtually every penny of additional resources that has been made available for the next three years is directed centrally by the Executive. That puts considerable pressure on local authorities to deliver on their core services.

(http://www.scottish.parliament.uk/official_report/cttee/local.htm)

However, against this it should be noted that Scottish local government is presently enjoying real growth of around 4.5 per cent in grants - the highest 
annual percentages since the mid-1970s. Moreover, the executive would counter that the extent of ring-fencing has been much exaggerated. According to their own figures it has only risen from eight per cent to ten per cent of aggregate external finance - the increase being accounted for by the excellence fund. The executive's view is that it looks to local government to deliver on broad, strategic national objectives and that hypothecation which may exist at present can be abolished once local outcome agreements are in place in areas such as personal nursing care (Scottish Parliament, 2001).

Local government finance has been the Achilles' heel of all the talk about partnership and joined-up working. Finance is the root of the problem which bedevils the central-local relationship. Local authority self-finance expenditure remains at around 20 per cent - the high degree of dependency weakening local autonomy and accountability. Scottish local councils remain as dependent on national grants as their counterparts in England. Wilson (2001: 302) refers to the 'financial grip' Whitehall has on English local councils - the Scottish Executive retains a similar grip in Scotland. As in England, no significant change in the central-local balance of funding is on the agenda.

The emphasis of recent reforms has been to introduce more stability with the introduction of three-year settlements for grant allocations. Some of the tension in central-local relations has been eased with the relaxation of Scottish Executive financial controls. However, in terms of finance the evidence that does exist suggests more councils are 'overspending' (in terms of grant-aided expenditure - GAE) post-devolution. Between 1995/96 and 2001/2 the excess of local authority budgets over GAE has increased from 1.6 per cent to 6.4 per cent (Midwinter, 2001).

\section{PARTNERSHIP FRAMEWORK}

At the 'national' (UK) level there has been a renewed emphasis on partnership since the election of the Labour administration in 1997. However, unlike the UK government, the Scottish Executive has considered central-local relations as a topic in its own right. In May 2001 the Executive Minister for Finance and Local Government, Angus MacKay, signed a partnership framework with COSLA. The framework document outlines the basis upon which the executive and local government will seek to work in partnership in their shared responsibility of serving the people of Scotland. MacKay, speaking at the signing ceremony in Edinburgh City Chambers, said:

Signing this framework today with COSLA's President, Norman Murray, is a clear indication of the importance the Executive places on 
working constructively with Local Government. It is important that we consult with each other and communicate effectively wherever possible so that we can all deliver the levels of service that Scotland deserves. (Scottish Executive, 2001a)

COSLA also welcomed the introduction of the partnership framework. Its president, Norman Murray, commented:

Partnership working between the two democratically elected levels of government in Scotland is essential and can only be achieved through parity of esteem, which this framework clearly defines. To work constructively together, we must operate in a climate of openness, transparency and trust and I believe the Framework will help us achieve that in order to deliver the highest quality possible services to our communities. (Scottish Executive, 2001a)

This is the first time there has been a clear written protocol between the two levels of government in Scotland. At a symbolic level it demonstrates a commitment to shared working. It follows the McIntosh Commission recommendation that a formal working agreement should be established between local government and the Scottish Executive to supersede the informal framework for partnership working document which was put in place after the 1997 general election.

The partnership framework emphasises mutual respect as the foundation of the relationship between the executive and local councils, recognising that each other's roles and functions are both distinct and complementary. Operationally, this respect should manifest itself in engagement, consultation, public announcements, and the exchange of information and ongoing meetings between the executive and COSLA/local councils. This would involve the establishment of such institutional devices as the leadership advisory forum. From within local government circles the framework is viewed as a useful device. It will remind the executive's civil servants and ministers of protocol and the requirement for consultation and joint working in a wide range of policies.

\section{DOES DEVOLUTION MATTER?}

At first glance, central-local relations in Scotland appear very similar to those in England and Wales, with partnership dominating the language in all three countries. However, beyond the similar party political rhetoric there is no doubt that the story of central-local relations in Scotland is already significantly different from that to be told about England and Wales. 
The key difference in central-local relations in England and Scotland post-devolution is that there is a discernible approach in the Scottish Executive to the subject. It has focused on central-local relations as a topic in its own right - not simply a by-product of policy changes in other areas. It is possible that the smaller scale of government in Edinburgh, compared to the fragmentation of Westminster and Whitehall, heightens its capacity to adopt a more co-ordinated integrated approach. It also has the capacity to make very different settlements in terms of finance than is the case in England. Empirical data does not yet exist to make robust judgements about how the executive has exercised this autonomy.

Unlike in England, central-local relations in Scotland cannot simply be viewed as a by-product of changes elsewhere. It was and remains high on the political agenda post-devolution. Since devolution, Scotland's new governing institutions have had to handle a report with an exclusive focus on parliament-local government relations (McIntosh), another dealing with local democracy (Kerley), and a third examining managerial change (MacNish). It has overseen Best Value and community planning task forces bringing together executive and local government interests, published a partnership framework as well as reviewing financial relations (albeit not comprehensively) with COSLA. All of these developments are crucial to central-local relations in Scotland.

Another difference with England is that the regulatory oversight arrangements are more 'light touch'. Although there have been changes in the way the Scottish Executive undertakes its oversight role, it has not gone down the same audit and inspectoral path as England has. The Accounts Commission does not have the same Best Value inspectoral remit as the Audit Commission. There is no housing inspectorate in Scotland. Best Value remains a voluntary exercise and has yet to appear on the statute book, reform of political structures via the Leadership Advisory Panel has been governed by suggestion and guidance, not instruction. Informal guidance as opposed to formal instruction has been the order of the day. This possibly reflects the intimacy and interpersonal connections that exist in the smaller scale intergovernmental networks in Scotland. An alternative interpretation is that the docility of local councils in Scotland means that a light-touch approach has been sufficient. Scottish local government is Labour-dominated and ambitious council leaders may not want to be seen 'rocking the boat'.

Other changes in regulatory oversight arrangements have seen the various inspectorates and Scottish Homes experience structural and policy change. Audit Scotland was established to combine the workings of the Scottish division of the National Audit Office and the Accounts Commission. The new Housing Bill will see the regulatory oversight role of 
Scottish Homes (re-named Communities Scotland) extended to local councils. A recent consultation paper on reform of the public sector ombudsmen system in Scotland proposes establishing a one-stop shop combining the offices of the Scottish Parliamentary, Health Service, Local Government and Housing Association Ombudsmen (see Scottish Executive, 2001b)

Devolution has changed the framework that 'governs' Scottish local government. There have been changes in ministerial responsibility for local government within the executive as well as enhanced parliamentary scrutiny of local government through the committees, including the relevant functional committees, and local government, finance and audit. These developments themselves have increased the transparency and accountability of local government in Scotland.

Devolution has also brought into sharper focus the divisions within Scotland's only association of local councils - COSLA. Glasgow, Falkirk and Clackmannanshire resigned, forcing it to streamline its operation and deliver 'core' services to its members to ensure it remains financially stable and has a long-term future. It is rather ironic that, post-devolution, when there is a constant flow of consultation documents from the executive and numerous parliamentary committees seeking expert evidence, Scotland's only umbrella group for local authorities is contracting. COSLA is required to react almost daily to new policy announcements and press releases.

Despite the 'light touch' regulatory approach noted above, the Scottish Executive has imposed a clear agenda on local councils. Viewed from local government, we have now had the Scottish Executive via the Leadership Advisory Panel recommending how councils should organise themselves internally, the Best Value policy imposing one managerial blueprint for all, and the financial reforms dictating how new monies should be spent whilst capping powers are retained. The Scottish Executive would appear to be just as concerned as national government with dictating how councils operate internally, even if its strategy of imposing its agenda is more subtle. Detailed prescriptive and direct control is evident in Scotland, if a little harder to detect.

However, as yet, some of the concerns expressed over devolution have not materialised - for example, loss of functions, loss of funding. The executive's policy priorities are health, education, roads and social inclusion. Local government is central to the delivery of three of these and involved in joint working and partnerships with health authorities over community care. At present, the policy and performance management frameworks for local government, although prescriptive at a macro-level do not involve detailed micro-level (that is, individual authority) interventions - local discretion largely remains in place. However, as in England and 
Wales, Scottish councils remain reliant on nationally distributed grants. The financial reforms taking place shift the emphasis to outputs and outcomes, with the executive prioritising spending in key areas.

Senior government politicians and policy advisers in Downing Street have long seen Labour local councils as the 'Achilles' heel' of New Labour, the programme of modernisation is designed to lessen their 'electoral liability' status. The message from the government nationally is 'modernise or perish' (Wilson, 2000: 280). Mair (2000) has noted evidence of similar thinking in the Scottish Executive.

Whilst not resorting to the same prescription/inspection as the DTLR, the Scottish approach does bear some resemblance to it. It would appear politicians and civil servants in Scotland share some of the same scepticism as their counterparts in England regarding local councils' capacity to deliver. The Scottish Executive appears to have a similar attitude to local councils as its counterpart in Westminster and Whitehall. The autonomy granted to local councils has to be earned and is conditional (Jones and Stewart, 2002 same issue).

Important movement took place in the understanding of the relationship between executive and local government during the first year of the new parliament (Mair, 2000: 109). In particular, Mair points to the McIntosh Commission Report's recommendation that councils should only retain their present powers and responsibilities if they accept the executive's reforms. Councils have to be seen to deliver services efficiently and effectively, improve the transparency and inclusiveness of local decisionmaking and scrutinise their own performance more effectively (2000: 111). Although recommendations concerning reform, covenants and working agreements were agreed and carried forward, the substantive recommendations which would have potentially limited the executive's control over councils were either rejected or deferred. Wilson (2001: 306) reports a 'strong streak of centralism' remaining in Whitehall - the Scottish Executive's streak may not be as strong but it is still evident.

Despite its success in imposing its agenda, the Scottish Executive has, at least to date, been less successful in delivering on it. Reflecting its nonexecutant capacity the executive is reliant on local councils, among others, to deliver on its social justice agenda. To date little evidence is available, but it is delivery across a whole range of social policy areas that will be the yardsticks for judgements as to the success of both central-local partnerships and devolution.

If the evidence of the impact of Best Value and 'modernisation' is anything to go by, the executive may run into difficulty. Despite the fact that the parties that form the Scottish Executive (Labour and Liberal Democrats) control (or are coalition partners) in 23 out of 32 council administrations the 
modernisation strategy has met firm resistance within Scottish local government. The proposals for adopting an executive model (a cabinet system), the failure to undertake a comprehensive review of local government finance and the recent proposals for democratic renewal (including proportional representation) have all been subject to criticism. The dominant Labour group in the Convention of Scottish Local Authorities recently rejected a move towards a proportional representation voting system.

Devolution has not and will not magic away the dilemmas of governing. The Scottish Executive has confronted the same problem with which Whitehall is very familiar - that of reconciling local discretion with national priorities. The prioritisation to date has been in favour of the latter.

Like the UK government the Scottish Executive has received much criticism over its lack of impact of service delivery outcomes. Two-year anniversary report cards on the Scottish Parliament and Executive were much kinder to the former than the latter. Given the non-executant nature of the executive it is likely that the focus of much of the attention in the next two years will be on local councils. Failure to deliver will impose serious strains on the much-hyped central-local partnership.

\section{NOTES}

1. For the ongoing story of central-local relations in Scotland post-devolution see the Constitution Unit/Economic and Social Research Council/Leverhulme Trust quarterly reports on local government in Scotland http://www.ucl.ac.uk/constitutionunit/leverh/pub.htm.

\section{REFERENCES}

Alexander, A., 1997, 'Scotland's Parliament and Scottish Local Government: Conditions for a Stable Relationship', Scottish Affairs, 19.

Best Value Task Force, 2000, Best Value in Local Government: Long Term Arrangements (Edinburgh: Scottish Executive).

Clarke, J., 2000, 'Kerley Set to Test Strength of Holyrood Coalition', Holyrood News, 29 June.

Community Planning Working Group, 1998, Report of the Community Planning Working Group (Edinburgh: Scottish Office).

DETR, 1998, Modernising Local Government - Improving Local Services through Best Value (London: DETR).

Dunleavy, P., 1997, 'The Constitution', in P. Dunleavy et al. (eds.), Developments in British Politics 5 (Basingstoke: MacMillan).

Heclo, H. and A. Wildavsky, 1981, The Private Government of Public Money (2nd edn., London: MacMillan).

Himsworth, C.M.G., 1998, 'New Devolution: New Dangers For Local Government?' Scottish Affairs, 24. 
Hood, C. et al., 1999, Regulation Inside Government (Oxford University Press).

Hood, J. and N. McGarvey, 2002, 'Managing the Risks of Public-Private Partnerships in Scottish Local Government', Policy Studies, 23/1.

House of Lords, 1996, Select Committee on Relations between Central and Local Government vols.I-III (London: HMSO).

Jones, G. and J. Stewart, 2002, 'Central-Local Relations Since the Layfield Report', this volume, pp.7-28.

Kerley Report, 2000, The Report of the Renewing Local Democracy Working Group (Edinburgh: Scottish Executive).

Leach, S. and D. Wilson, 2000, Local Political Leadership (London: The Policy Press).

Leadership Advisory Panel Report, 2001, Scottish Local Government's Self-Review of its Political Management Structures Report of the Leadership Advisory Panel, http://www.scotland.gov.uk/library3/localgov/rlap-00.asp.

Lloyd, G. and B. Illsley, 1999, 'Community Planning - A New Way Forward for Scotland', Town and Country Planning, 68/1.

Lowndes, V., 1999, 'Rebuilding Trust in Central/Local Relations: Policy or Passion', Local Government Studies, 25/1, pp.116-36.

Mair, C., 2000, 'The Executive and Local Government', in G. Hassan and C. Warhurst (eds.), The New Scottish Politics: The First Year of the Scottish Parliament (Edinburgh: The Stationery Office).

McIntosh Commission on Local Government and the Scottish Parliament, 1999, Moving Forward: Local Government and the Scottish Parliament (Edinburgh: The Stationery Office).

McGarvey, N., 2001a, 'New Scottish Politics, New Texts Required', British Journal of Politics and International Relations, 3/3, pp.427-44.

McGarvey, N., 2001b, 'New Perspectives on Accountability', Public Administration, 79/4, pp.949-54.

Midwinter, A., 2000, 'McIntosh on Governance and Accountability', Local Government Studies, 26/2, pp.1-6.

Midwinter, A., 2001, Written Memorandum to Local Government Finance Inquiry of the Scottish Parliament.

Midwinter, A. and N. McGarvey, 1997, 'The Reformed System of Local Government Finance in Scotland', Policy and Politics, 25/2, pp.143-52.

Midwinter, A. and N. McGarvey, 1999, 'Developing Best Value in Scotland: Concepts and Contradictions', Local Government Studies, 25/2, pp.87-101.

Midwinter, A and N. McGarvey, 2001a, 'The New Accountability? Devolution and Expenditure Politics in Scotland', Public Money and Management, 21/3, pp.47-55.

Midwinter, A. and N. McGarvey, 2001b, 'In Search of the Regulatory State: Evidence from Scotland', Public Administration, 79/4, pp.825-49.

Midwinter, A., M. Keating and J. Mitchell, 1991, Politics and Public Policy in Scotland (Basingstoke: MacMillan).

Mitchell, J., 2001, 'The Study of Scottish Politics Post-Devolution: New Evidence, New Analysis and New Methods?' West European Politics, 24/4, pp.216-23.

Rhodes, R.A.W., 1988, Beyond Westminster and Whitehall (London: Unwin Hyman).

Rhodes, R.A.W., 1997, Understanding Governance (Buckingham: Open University).

Scottish Executive, 1999, Report of the Commission on Local Government at the Scottish Parliament - The Scottish Executive Response (Edinburgh: Scottish Executive).

Scottish Office, 1997, Scotland's Parliament cm 3658 (Edinburgh: The Stationery Office).

Scottish Executive, 2001b, Scottish Executive Press Release E1194/2001, 'Mackay Signs Local Government Partnership Framework with COSLA', 3 May 2001, http://www.scotland.gov.uk/news/2001/05/se1194.asp.

Scottish Executive, 2001b, A Modern Complaints System. Consultation on Proposals for Public Sector Ombudsmen in Scotland. Laid before the Scottish Parliament by the 
Scottish Ministers July 2001SE/2001/139, http://www.scotland.gov.uk/consultations/ localgov/ppso-00.asp.

Scottish Parliament, 2001, Local Government Committee Minutes 2 Oct.

Sinclair, D., 1997, 'Local Government and a Scottish Parliament', Scottish Affairs, 19.

Stoker, G. (ed.), 1999, The New Management of British Local Governance (Basingstoke: MacMillan).

Stoker, G. (ed.), 2000, The New Politics of British Local Governance (Basingstoke: MacMillan).

Widdicombe, 1986, Report of the Committee of Inquiry into the Conduct of Local Authority Business, Cmnd 9797 (London: HMSO).

Wilson, D., 2000, 'New Labour, New Local Governance?' in R. Pyper and L. Robins (ed.), United Kingdom Governance (Basingstoke: MacMillan).

Wilson, D., 2001, 'Local Government: Balancing Diversity and Uniformity', Parliamentary Affairs, 54/2, pp.289-307. 